DOI: https://doi.org/10.3126/njdrs.v15i0.31596

\title{
Locating Development as a New 'Discipline'
}

\author{
Mahendra Sapkota, PhD \\ Visiting Faculty, Department of Development Studies, School of Arts Kathmandu University and \\ CDRD, Tribhuvan University and pursuing Post-doctoral study in Anthropology \\ Email for correspondence: sapkota.mahendra27@gmail.com
}

\begin{abstract}
Development is an essentially contested discourse and debated issue; both in theoretical and empirical world. With this proposition, this paper offers a synthesis of multifaceted dimensions of development. Methodologically the paper follows a critical perspective, though it is based only on secondary data and prepared as a synthesis paper drawing insights from various literatures. The major arguments of the paper include that: development is constantly becoming contradictory, involving different actors, agencies, and structures. The paper concludes with the remark that development is being questioned elsewhere, and its conclusion in terms of theory and practice is yet contradictory to have universal validation.
\end{abstract}

Key words: Contestation, development, metaphysics, discourse

\section{Background}

The concept of development is not neutral but it happens to be fundamentally multidimensional and value-loaded. In many countries of the contemporary world, particularly in the Global South, discourse of development is being questioned. Though the notion of development has become a melting pot for all kinds of academia, research and policy debates, its meaning in everyday lives has become essentially diverse and often contradictory too. It was once a worldwide belief that development is primarily concerned with economic growth. However, the theory and practice of development has become multidimensional going beyond the growth approach of mainstream paradigm. It is not a venture limited to a certain niche within given social, economic or political processes, but influences, directly or indirectly, the lives of most people, and specifically so in the countries of the South (Johnson \& Wilson, 2006; Nash, 2009; Geiser, 2014). Indeed, the identity of people in a society can be collective but is always socially constructed in a set of existing power relations.

The contestation is becoming a universal phenomenon in questioning the traditional development discourses and practices and establishing the new alternatives in place of them. The roles and duties of the state, state actors (SAs), non-state actors (NSAs), authorities, assumptions, research works and academia are becoming contested by the contrasting understandings of mainstream development. The mainstream of development, therefore, has been created as the established frameworks and practices, often defined and advanced by governmental agencies and large donor institutions. However, alternative perspectives of development and micronarratives have been largely ignored despite their diverse emergence. In contemporary development studies, it has been using in the context of critique, and to describe frameworks derived from, or predominantly developed in, the 
global North and that support neoliberal economic approaches and governance models in line with the current status quo (Hayness, 2015; Kothari, 2016).

\section{Niche of 'Discourse'}

All things are subject to interpretation; whichever interpretation prevails at a given time is a function of power and not truth (Friedrich Nietzche, 2015).

The term 'discourse' explores a variety of topics and meanings in social science research. In a Foucauldian sense, it refers to systematic and organized knowledge or experience, which represses alternative through its dominance or hegemony (Foucault, 2001). This paper has analysed the notion of rural development as a 'discourse', which critically searches conceptual, theoretical and normative arguments, and with this, it identifies contested issues. As we see historically, the study of development as a discourse is a relatively new field, inspired in part by Edward Said's Orientalism. Orientalism, Said (1979) writes, is a 'systematic discipline by which European culture was able to manage - and even produce - the Orient politically, sociologically, militarily, ideologically, scientifically, and imaginatively during the post-Enlightenment period' (p. 3). This definition is instructive also for the study of development as a representational practice. Edward Said argues in the introduction to Orientalism that there is 'no such thing as a delivered presence; there is only a re-presence, or a representation' (1979, p. 21). Geiser (2014) maintains that the discourse is not just composed of the words but that words can become potentially powerful through their normative and strategic usage in social interaction (p. 4).

In global literature of development, the crisis in development discourse can be seen in many ways (Bernstein, 1995; Escobar, 1992, 1995/2011). The claims of liberals, neo-liberals and modernists often related to functional ideology of the development while the Marxists rely on conflict and dialectical structure of society. In between these two grad narratives, there are other theoretical developments including post-structural, post-modern and post-developmental. The liberal ideology often sees development as an essentially good idea and scrutinized with the actual implementation of development project with epistemological position of modernization. It tries to propose reforms to the workings of development institutions and functional strategies. The Marxist and neo-Marxists, on the other hand, critically view actual existing development institutions and practices as essentially promoting capitalist expansion and exploitation in the developing world. Ideologically they follow dialectical epistemology of political economy. Despite these contrasting political postures, as argued (Fujikura, 2013), both schools of thought have been operated within similar problematics, focusing on the gap what development was supposed to do and its actual performance. In consequence, radical critiques are still organized around the political naïve questions: "what development is, for what it is derived and by whom it is operated so far?

In this setting, it is worthwhile to mention the prelude of the 'Anti-Politics Machine', initially published in 1990 where James Ferguson composed of the centrality of "development" in our times (Ferguson, 1990). Ferguson tried to investigate how the "development discourse" functions, that is, the manner by which the language and practices utilized by development experts impact the courses in which development is conveyed, and the unintended results it encourages. The net impact of development, he contends, has been to "de-politicize" questions of asset allotment and to reinforce bureaucratic force. On the impact the anti-politics machine has had on resulting critiques of development which is essentially contested and fluid in nature (Cornwall, 2007; Escobar, 2001). 
Indeed, the question of 'development for whom' is more important rather than question of 'what the development is' and 'how has been it distributed so far'. An uneven distribution of development among poor rural people and disadvantaged sections of the society (Payne, 2005; Frank, 1978) has created an immediate crisis in the development. In the same context, Escobar seems (1992) to be apparent in viewing the development critically as a contested discourse. It seems a virtual shadow of larger project of dominant 'western modernity'. Bernstein $(2006,2010)$ critically observes development as a competitive domain of discourses. The words and jargons used in such discourses can have powerful potentials of influence through their normative and strategic usage in social interactions. However, the issue and problems of rural areas have been largely overlooked by the domination of established structures like the State, market and non-governmental organizations including civil society groups (Sapkota \& Chaudhary, 2016). In consequence, the dilemma of development has become apparent it inters of its knowledge, experience and policy constraints. As reflected: discourses systematically organize knowledge and experience, and repress alternatives through their dominance (Outhwaite \& Bottomore, 1993). Their use in development policy may offer little hope of the world free of poverty that they are used to evoke (Cornwall \& Brock, 2005).

\section{The 'Metaphysics' of Development}

Development is an ideological construct, which bears some metaphysical meaning and interpretations. Metaphysics of development can be illustrated as what development is in reality and beyond that. Some of the metaphysical questions in this regard include, but not limited to the following:

- What is this development? (and what not is)

- Does development really exist (or is it non-existent?)

- Is it an abstract/ tangible notion (or concrete/ intangible)?

- Is it something visible or invisible?

- Is it the end or the means? (of people/ society)

- Is it compulsory to go with or to follow with?

- Is it something we all take for granted?

- Is it something nobody can disagree with?

- Is it 'in between' or 'beyond that' or 'nothing than' or 'everything' or what?

The meanings of development range from simple to complex; traditional to modern/ postmodern; and mainstream to the alternative. In simple terms, development means to earn high, to learn more; to achieve more; to be happy and to be cherished. Moreover, the dictionary meaning of development include growth, blossoming, progress, extension, expansion, improvement and transformation. However, in terms of metaphysics, all these things that are attributes or features of development characteristics, are debated and contested. What does 'growth' means and is it same for all-and whether its counter degrowth matter or not? Similarly, the concept of 'positive' and 'negative' are also relative perspectivessomething positive for one cannot be necessarily be the positive to the other. The terms that often used in development discourse, such as the idea of traditional and modern, underdevelopment and development/ post-development, etc.are also relative terms that are not absolutely valid for the people of all countries, societies and communities. Similarly, the debate of global south vs north, micro vs macro, exogenous vs endogenous, agency and structure and mainstream vs alternative should be viewed dialectally. 
Development thus is an integral part of political debate, economic planning and academic discussions. It carries multiple and diverse meanings for different groups and peoples. What development is, or what it is not meant to be - this can be contested and even lead to violence. A general understanding is that development is doing something about the people, helping them, bringing them out of the poverty, enabling them to have a decent life with greater respect and dignity.Following this, development is a theoretical-empirical continuum that involves a multidimensional setting of social, political and economic history, contemporary life and future of people, society and the state. Despite this definition, however, metaphysically, neither any conclusion of development is 'possible'; nor its epistemology (i.e. whose 'reality' counts in development) and the ontology (i.e. who constructs 'development' to its being) is final as an absolute and universal.

\section{Issues/Debates on the Discourse: Crisis and the Thrust of Alternative Thinking}

In 'Encountering Development', one of the most widely read and debated literature, Escobar sought to provide a general view of the historical construction of development and the third world as a whole. He has critiqued modernization interventions of development as blueprint exemplar to produce change without transforming the nature of the discourse as a whole. As Escobar (1995) argues, thinking about development in terms of discourse enables us to maintain a focus on power and domination, while at the same time exploring the discourse's conditions of possibility as well as its effects. Brought on by critical thinking, Escobar compared powerful social movements and the discourse of development to contribute the critiques of intellectual inquiry and political action for alternative futures. With reference to the question of 'alternatives', Escobar argues that we should no longer talk in terms of 'development alternatives' since to do so is to contribute to the continuing hegemony of development. Instead, he suggests, we should talk of 'alternatives to development, that is, the rejection of the entire paradigm altogether” (1995, p. 215). Again, to quote Escobar (1992):

Most critiques of development, articulated within the epistemological and cultural space it defines, have reached an impasse. Thus, the present crisis does not call for a 'better' way of doing development, not even for 'another development'. A critique of discourse and practice of development, however, can help clear the ground for a more radical collective imagining of alternative futures (p. 21-22).

In Asian and Latin American studies, western civilization and modernity was confronted by the dark side of progress in the name of wake of the affluent society to be granted with 'modernization'. The critics reflect that development interventions and social forces were manually constructed to foster growth or development just as a 'shadow' of Western modernity and historicity. It was development of underdevelopment that contributed to foster poverty, inequality and dependency in developing countries (Amin, 2010; O'neil, 2015). In this regard, Sachs (1992) seems very critical in his famous work The Development Dictionary where he maintained a manual of post developmental thought and argued that the modern age of development was proclaimed over and done with:

The idea of development stands like a ruin in the intellectual landscape. Delusion and disappointment, failures and crimes have been the steady companions of development and they tell a common story: it did not work. Moreover, the historical conditions which catapulted the idea into prominence have vanished: development has become outdated. But above all, the hopes and desires which made the idea fly, are now exhausted: development has grown obsolete (Sachs, 1992, p. 1). 


\section{Freedom, Participation and Identity}

In development discourse, Amartya Sen (2000 and 2011) has conceptualized different theoretical elements including political freedom, economic facilities, social opportunities, transparency guarantees, capability development, entitlement, protective security, identity and so on. He elsewhere argues that development can be seen as a process of expanding the real freedoms that people enjoy. In the opening sentence of Development as Freedom (2000), he maintains that the goal of development is the "promotion and expansion of valuable capabilities." Following this, freedom is central to the process of development for the assessment of the progress and the achievement of development. He finally concludes that 'development is indeed a momentous engagement with freedom's possibilities' (p. 298). This is how he continues:

We live in a world of unprecedented opulence, a kind that would have been hard to even to imagine a century or two ago...... and yet we also live in a world with remarkable deprivation, destitution and oppression...overcoming these problems is a central part of the exercise of development ( $\mathrm{p}, \mathrm{xi})$

In recent years, the development discourse has been gradually lifting towards the issues of identity, social justice and people's participation. In this regard, Sen (2007) prefers multiple identities, which he perceives as a notion that an individual is made up of various characteristics and components that work in unison to create the whole being. Cautioning against those who may selectively emphasize an individual's or people group's particular characteristics over others for their personal or political gain, Sen says that we should remain aware of the 'politics of partition', which serves to divide and alienate minorities including the issues of refugees and Islamophobia. In light of this, he goes on to stress the importance of a better understanding of the multiplicity of identities, so as to foster improved social cohesion and inclusivity in the long term. Again, moving on to a question about the role of growth and human development in making policy, Sen asserts that the distinction that is presently being made between growth and human development is a 'fake horse race' (Sen, 2015).

\section{Power, Agency and Structure}

Pierre Bourdieu has done classic works in viewing the power relations in societies. His research pioneered such influential concepts as capital (which opposed to traditional economic forms of capital and proposes cultural, social and symbolic forms of capital), the habitus (shaped by past events/ structures and current practices/ structures) and the filed or location (various social and institutional arenas). Bourdieu's work was primarily concerned with the dynamics of power in society, and especially the diverse and subtle ways in which power is transferred and social order maintained within and across generations (Bourdieu, 1980, 1986). He approaches power within the context of a comprehensive 'theory of society' which - like that of Foucault - we can't possibly do justice to here, or easily express in the form of applied methods (Navarro, 2006). While Foucault sees power as 'ubiquitous' and beyond agency or structure, Bourdieu sees power as culturally and symbolically created, and constantly re-legitimized through an interplay of agency and structure. He has proposed the power to be a 'doxa', which is the combination of both orthodox and heterodox norms and beliefs- the unstated, taken-for-granted assumptions or 'common sense' behind the distinctions we make. (Bourdieu, 1984, p. 471). As part of social science research and development studies, his theories and approaches of Bourdieu can be used to explain how people can resist power and domination in one [field] and express complicity in another. 
The debates in structure and agency for the interplay or power are critically reflected by various scholars. The contribution of Anthony Giddens seems quite remarkable in this regard who is well known for his theory of structuration and his holistic view of modern societies. Giddens emphasises the social constructs of power, modernity and institutions as the three core subject matter of contemporary sociology. He rejects traditional approaches of positivism in social science and notes that society only has form, and that form only has effects on people, insofar as structure is produced and reproduced in what people do (Giddens, 1971). He compares and contrasts Durkheim's positivist sociological paradigm and Weber's functionalist paradigm to critically envision the agency and motives of individuals. He then rejects both of those approaches, stating that while society is not a collective reality, nor should the individual be treated as the central unit of analysis. Rather he uses the logic of hermeneutic tradition (from interpretative sociology) to argue for the importance of agency in sociological theory, claiming that human social actors are always to some degree knowledgeable about what they are doing. Social order is therefore a result of some pre-planned social actions, not automatic evolutionary response (Giddens 1984, 2009). In empirical sense, the challenges and problems at the grassroots are much more complex and largely overlooked which call for a critical and innovative thinking, going beyond established lines of framing or theorizing of development in general and rural development in particular. As Crush (1995) rightly proposes:

The primary purpose of the development text (like most others) is to convince, to persuade, that this (and not that) is the way the world actually is and ought to be amended. They are rather assembled within a vast hierarchical apparatus of knowledge production and consumption sometimes known as the 'development industry'. This industry is itself implicated in the operation of networks and of power and domination that in the Twentieth Century have come to encompass the entire globe."(p. 5).

To reemphasize, development is crisis-driven where the critique remains open-folded, including various dimensions, such as growth and development; historicity, hegemony, and emancipation; and the emergence of new actors (movements, revolutions, identities, market, State). Therefore, as a discourse, contestation(s) in development is constantly emerging. The word 'contestation' denotes to every day politics that becomes an ensemble of practices, discourses and institutions that seek to establish a certain order and to organize social life in conditions that are always potentially subject to conflict (Geiser, 2014; Geiser \& Rist, 2009). It seems to be quite 'contrasting' and 'contesting'. To reflect, Michel Foucault's forceful articulation of an intrinsic and irreversible relationship between power and knowledge is of immense value to the analysis of development and North-South relations. He maintained that modern discoursed are found on an appeal to truth. He maintained that "truth is not outside of power each society has its own regime of truth, its general politics of truth" (Foucault, 1980a, p. 131). He further opines that it allows us to 'stand detached from [development], bracketing its familiarity, in order to analyse the theoretical/practical context with which it has been associated' (Foucault, 1986, p. 3).

\section{Emerging Frontiers of 'Development'}

Though classical approach of development is growth-centric and is largely Euro-centric, last two decades of academic world has witnessed an emerging notion of development studies. It has become an interdisciplinary discipline of social science that includes multiple issues of development involving 
the issues of discourse, theory, paradigm and practices. It has shifted from the singularity towards multiplicity; mainstream to alternative; and macro to micro perspective (Kothari, 2015; Pradella \& Marois, 2015). Indeed, this is a theoretical question which seems to be in crisis and needs to have an unavoidable deconstruction. To mention Pieterse (2010):

What is referred to as development theory' largely belongs to the level of grand theories, broad explanatory frameworks. This is part of its limited character. There is a lot that development theory does not talk about (p. 2).

The structure of power within the social context has been an ever debated issue in social science discourse. The ultimate source of power and its manifestations are essentially diverse. The scholars are divided in critiquing the way of constructing power and its shifting within the structure, agency and beyond them in a different context of social life. There has been an emergent question regarding the outcomes of development even though a tremendous amount of investment had been made in achieving those outcomes in terms of reduction of poverty and inequality and enhancement of sustainable livelihood for the rural poor. As a matter of fact, the development outcomes and well-being of people could be promoted by the one-way supply of investment for material needs without changing the power dynamics in the societies.

Consequently, there have been investigative models and frameworks to study the power relations in modern societies which have been part of contemporary development studies (Haynes, 2015). The meaning and practice of development has changed over time and in turn, development studies has gone with some significant deconstructions and reconstructions. The main characteristic in this change include the shifting of development thinking/ study/ practice from structuralism to constructivism, determinism to interpretivism, and from Eurocentrism to polycentrism. In this regard, some of the diverse fields emerged within the broader domain of 'development studies' can be listed as:

- Capitalist school of development including theory of development (i.e. modernization)

- Socialist school including theories of underdevelopment (dependency and world system)

- Neo-liberalism and development

- Post-developmental theory

- Anti-developmental critiques

- Globalization and anti-globalization and social movements

- Political economy of development

- Development economics (economics of development)

- Sociology of development

- Anthropology of development

- Governance and development

- Agrarian reform and development

- Gender studies and development

- Tourism and development

- Rural development

- Entrepreneurship, marketing and development

- Labor, remittances and development economics

- Non-state actors and CSOs in development 
Yet, this list can be more elaborated in the days to come. This setting of multiple specifications on development studies, however, can be challenged by a metaphysical question: whether the development prevails as an illusion or disillusion or it is happening in real? On the other hand, there is a never ending question of how development is connoted as an 'ideology'(development theory and their relevancies; western thoughts; and the three-worldism), and how to perceive it (either in terms of colonial, hegemonic, Global North vs South, American unipolar vs new poles). Similarly, new terrain of development (Post-Marxism, post-modernism, Orientalism, Subaltern studies, and post-structuralism) which are supposed to be the domains of literature and philosophy, have now become unavoidable readings in contemporary development studies.

When it became obvious that the classical approaches to development had failed or severely injured, several authors began to discuss the 'end of the development era' at the beginning of the nineties. Though it is about three decade ago stated, it is worthwhile to mention the crisis in modern development thinking. One famous quotation is of Wolfgang Sachs, who in 1992 stated in his wellknown book "The Development dictionary. A guide to knowledge as power":

The idea of development stands like a ruin in the intellectual landscape. Delusion and disappointment, failures and crimes have been the steady companions of development and they tell a common story: it did not work" (p. 1).

The 'structure' of development is becoming a complex paradox and, it is becoming puzzling dilemma how to see development theoretically and empirically or making a mixture of both. The critiques of modernization, ethnocentrism and universalism are going one, nevertheless these are the dominant notions of development in contemporary world. Unfortunate is that recent development concepts (including approaches and perspectives), such as human development, sustainable development, inclusive development, good governance, sustainable livelihood, community development, and alternative development all are serving towards the capitalistic school. In turn, they have become dominant discourse of development, and are still daunting the world of development. Moreover, they have been criticized as being more elite-centric and urban-biased (Sapkota, 2017).

\section{The Synthesis and Conclusion}

Globally, therefore, development has been a contested notion as it is becoming tired of 'grand' solutions and theories on the basis of critique of previous practice. Yet, sufficiency of the development theories to overcome the development challenges can be doubted. Most of the critiques of development stop fail to offer a unique perspective on future possibilities and the shape of the things to come. The alternatives and worldviews for the solutions of development problems are also questionable because questions such as who designs them and for whom become pertinent. The 'alternatives of development' versus 'development alternatives' is another dilemma in this regard. The relationship of developmentalism and politics is further complicated. In this context, the following questions are becoming pertinent in present context of development studies:

- What development is, or what it is not meant to be?

- If a theory offers knowledge and discourse, then what does a development practice do in turn?

- Why do the theories and practices, again, contradict with each other at the grassroots?

- How a theory of development, negotiates with development itself, and how with the class, culture, historical context and relations of power? 


\section{References}

Amin, S. (2010). From capitalism to civilization: Reconstructing the socialist perspective. New Delhi: Tulika Books.

Bernstein, H. (1995). Development studies and the Marxists. In U. Kothari (Ed.), A radical history of development studies: Individuals, institutions and ideologies. London: Zed Press. Retrieved from http://escholarship.org/uc/item/43f9g6qd.pdf\%3Borigin=repeccitec

Bernstein, H. (2006). Studying development/development studies. African Studies, 65(1), 45-62.

Bernstein, H. (2010). Introduction: Some questions concerning the productive forces. Journal of Agrarian Change, 10(3), 300-314.

Bourdieu, P. (1980). The logic of practice. Stanford, USA: Stanford University Press.

Bourdieu, P. (1984). Distinction: A social critique of the judgment of taste. London: Routledge.

Bourdieu, P. (1986). The forms of capital. Handbook of theory and research for the sociology of capital, 241-58. New York: Greenwood Press.

Cornwall, A. (2007). Buzzwords and fuzz words: Deconstructing development discourse. Development in practice, $17(4-5), 471-484$

Cornwall, A., \& Brock, K. (2005). What do buzzwords do for development policy? A critical look at 'participation', 'empowerment' and 'poverty reduction'. Third world quarterly, 26(7), 10431060.

Crush, J. (1995). Power of development. London: Routledge.

Escobar, A. (1992). Imagining a post-development Era? Critical thought. Development and social movements. Social Text, No. 31/32, Third World and Post-colonial Issues, pp. 20-56. Retrieved from http://www.jstor.org/stable/466217

Escobar, A. (1995). Encountering development: The making and unmaking of the Third World (reprinted in 2011). USA: Princeton University Press. Retrieved from http://200.41.82.27/536/1/ Escobar\%20Arturo_Encountering\%20development_cap\%201\%20al\%203.pdf

Escobar, A. (2001). Beyond the search for a paradigm? Post development and beyond. Development, 43/4, 11-14. Retrieved from https://link.springer.com/article/10.1057\%2Fpalgrave. development. 1110188

Ferguson, J. (1990). The anti-politics machine: 'Development', depoliticization and bureaucratic power in Lesotho. Cambridge: CUP Archive.

Foucault, M. (1980). The history of sexuality. New York: Vintage Books.

Foucault, M. (1986). Disciplinary power and subjection. Power, pp. 229-42.

Foucault, M. (2001). Madness and civilization: A history of insanity in the age of reason. London: Routledge.

Frank, A. G. (1978). Dependent accumulation and underdevelopment (pp. 148-9). London: Macmillan.

Fujikura, T. (2013). Discourses of awareness: Development, social movements and the practices of freedom in Nepal. Kathmandu: Martin Chautari.

Geiser, U. (2014). Conceptualizing 'Contested Development' - from Grand Narratives to the Nitty-gritty of the Everyday. In Sharma, S. R, Upreti, B. R., Manandhar, P., Sapkota, M. (Eds.). Contested development in Nepal: Experiences and reflections (pp. 1-25). Kathmandu: School of Arts, Kathmandu University and Nepal Centre for Contemporary Research (NCCR). 
Geiser, U., \& Rist, S. (Eds.). (2009). Decentralisation meets local complexity: Local struggles, state decentralisation and access to natural resources in South Asia and Latin America. (Vol. 4). pp. 15-55. Bern: NCCR North-South.

Giddens, A. (1971). Capitalism and modern social theory. An analysis of the writings of Marx, Durkheim and Max Weber. Cambridge: CUP

Giddens, A. (1984). The constitution of society. Outline of the theory of structuration. Cambridge: Polity Press.

Giddens, A. (2009). Sociology (6th ed.). Cambridge: Polity Press. Retrieved from https://ia800206. us.archive.org/15/items/Sociology_6_edition/Sociology_6_edition.pdf

Haynes, J. (2015). Development studies. New Delhi: Rawat Publication.

Johnson, H., \& Wilson, G. (2006). North-South/South-North partnerships: Closing the 'mutuality gap'. Public Administration and Development, 26(1), 71-80.

Kothari, U.(Ed.). (2016). A radical history of development studies: Individuals, institutions and ideologies. London: Zed Books Ltd.

Nash, K. (2009). Contemporary political sociology: Globalization, politics and power. New York, USA: John Wiley \& Sons.

Navarro, Z. (2006). In search of cultural interpretation of power. IDS Bulletin 37(6): 11-22.

Nietzche, F. (2015). Beyond good and evil. Irvine: Xist Publishing.

O'neil, P. H. (2015). Essentials of comparative politics: Fifth international student edition. New York: WW Norton \& Company.

Outhwaite, W., \& Bottomore, T. (1993). The Blackwell dictionary of twentieth-century social thought. Cambridge, USA: Blackwell Publishers Inc.

Payne, A. (2005). The global politics of unequal development. Basingstoke: Palgrave Macmilla

Pieterse, j. V. (2010). Development Theory. New Delhi: Sage Publications.

Pradella, L. \& Marois, T. (Eds.) (2015). Polarizing Development: Alternatives to Neoliberalism and the Crisis. Pluto Press.

Sachs, W. (Ed.) (1992). Development dictionary: A guide to knowledge as power. London and New York: Zed Books. Second edition published in 2010 and retrieved from http://shifter-magazine. com/wp-content/uploads/2015/09/wolfgang-sachs-the-development-dictionary-n-a-guide-toknowledge-as-power-2nd-ed-2010-1.pdf

Said, E. (1979). Orientalism. New York: Vintage Books.

Sapkota, M. (2017). Rise of ethnic movements and contested rural development in Nepal (An Unpublished Doctoral Thesis, Kathmandu University/Zurich University). Kathmandu: School of Arts.

Sapkota, M. \& Chaudhary, M. (2016). Development a contested discourse: An overview. Nepalese Journal of Development and Rural Studies, 13, 13-28.

Sen, A. (2000). Development as freedom. London: Oxford Paperbacks.

Sen, A. (2007). Identity and violence: The illusion of destiny. India: Penguin Books.

Sen, A. (2011). The idea of justice. USA: The Belknap Press of Harvard University Press.

Sen, A. (2015). Based on a public conversation with Amarty Sen: Critical reflections on identity and development. Retrieved from http://blogs.lse.ac.uk/southasia/2015/11/21/in-conversation-withamartya-sen-critical-reflections-on-identity-and-development/ 